\title{
Increased habitat structure does not always provide increased refuge from predation
}

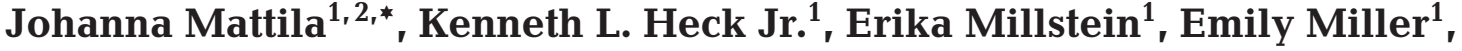 \\ Camilla Gustafsson ${ }^{1,2}$, Savannah Williams ${ }^{1}$, Dorothy Byron ${ }^{1}$
}

${ }^{1}$ Dauphin Island Sea Lab, 101 Bienville Boulevard, Dauphin Island, Alabama 35628, USA

${ }^{2}$ Present address: Husö Biological Station and Department of Biology, Environmental and Marine Biology, Åbo Akademi University, Akademigatan 1, 20500 Turku, Finland

\begin{abstract}
Submerged aquatic vegetation (SAV) usually hosts higher numbers of both invertebrates and fish than do unvegetated substrates. In addition, based on prior laboratory experiments predation risk is thought to decrease with increasing SAV biomass or stem/shoot density, resulting in higher abundance and diversity of potential prey species in dense vegetation. However, all previous tests of the effects of vegetation on prey capture have been similar: constant numbers of predators and prey have been tested at different vegetation densities. Because sampling has repeatedly shown that the abundance of both predators and prey increases with increasing SAV density, an experiment that tests the effects of increasing SAV density on prey capture would mirror reality more closely than would the design of prior experiments and would also allow predator and prey numbers to increase. Thus, in laboratory trials we increased the number of predators (pinfish Lagodon rhomboides [Linnaeus]) and prey (grass shrimp Palaemonetes pugio Hulthuis) in proportion to increases in SAV shoot density to re-evaluate whether increasing SAV density altered prey survival rates under these more realistic conditions. Treatments included an unvegetated substrate and 3 different densities $\left(400,2000\right.$ and 4000 leaves $\mathrm{m}^{-2}$ of artificial SAV (mimicking turtlegrass Thalassia testudinum Banks and Sol). Our results conflicted with those of prior experiments and showed no significant differences in grass shrimp survival among the different SAV densities (although there was greater grass shrimp survival in SAV than on unvegetated substrate), and indicated that increasing vegetation density will not consistently lead to proportionally greater prey survival rates.
\end{abstract}

KEY WORDS: Experiment $\cdot$ Lagodon rhomboides $\cdot$ Palaemonetes pugio $\cdot$ Prey survival $\cdot$ Seagrass

\section{INTRODUCTION}

In shallow coastal waters, invertebrate and fish abundances, species richness and biomass increase with increasing habitat complexity (Orth et al. 1984, Edgar \& Shaw 1995). It is also commonly believed that reduced predation risk results in elevated densities of invertebrates and fish that inhabit soft bottom areas containing structurally complex submerged aquatic vegetation (SAV) (Gotceitas \& Colgan 1987, Gotceitas 1990a, Laprise \& Blaber 1992). Predation risk is generally thought to decrease with increasing habitat complexity, and many experimental studies have shown that increases in habitat structure decrease predation efficiency of fish and other epibenthic predators (Savino \& Stein 1982, Minello \& Zimmerman 1983, Johns \& Mann 1987, Gotceitas 1990b).

Experimental design in all previous laboratory tests of the effects of vegetation density on prey capture has been similar: the effects of a constant number of predators on a constant number of prey have been tested at different levels of habitat structure. However, as shown repeatedly by in situ studies, both the numbers of prey and predators increase with increasing vegetation density (Werner et al. 1977, Heck et al. 1989, Wyda et al. 2002). Thus, the results from laboratory 
experiments done to date, in which predator and prey densities were kept constant as vegetation density was increased, may have incompletely represented natural conditions and resulted in an imperfect understanding of how SAV influences predator-prey interactions in nature.

Since the previous experimental setups have not satisfactorily mirrored natural situations, we hypothesized that if the abundances of predators and prey increased with increasing surface area, as might be expected in field settings, predation pressure might be unchanged as the complexity of SAV habitats increased. To test this hypothesis we carried out mesocosm studies using artificial SAV habitats of varying density with grass shrimp Palaemonetes pugio as prey and pinfish Lagodon rhomboides as the predator. Our intention was to use the same mesocosm design as in previous studies to enable comparisons with them. We also intentionally chose only one type of seagrass leaf morphology to minimize problems with interpretation (Edgar \& Robertson 1992). Further, in the first experiment we kept the ratio between the abundance of predators and prey constant in relation to available surface area (SAV plus tank area) across all treatments, while in the second experiment ratios of predator:prey were scaled only to the surface of SAV (not including the area of the tank).

\section{MATERIALS AND METHODS}

Expt 1. Expt 1 was conducted in July and August 1997 in a 3 compartment water table. The compartment dimensions and other basic experimental conditions are given in Table 1. The compartments contained a vertical outflow pipe (diameter $[\varnothing]=4 \mathrm{~cm}$ ), the open end of which was covered with fine mesh cloth (mesh $\varnothing=0.5 \mathrm{~mm}$ ) to prevent animals from escaping during the experiments. Complexity was varied by adding different densities of artificial seagrass (Table 1) in the form of polypropylene ribbons tied to $\operatorname{Vexar}^{\mathrm{TM}}$ mesh (that was buried in the sand) at the specific treatment density. Polypropylene ribbon is a good mimic of turtlegrass Thalassia testudinum, a common seagrass species in the Gulf of Mexico and Caribbean Sea, and has previously been used in several predation experiments (e.g. James \& Heck 1994, Boström \& Mattila 1999). Three different densities of seagrass $\left(400,2000\right.$ and 4000 leaves $\mathrm{m}^{-2}$, Table 2) and a bare sand treatment were tested in the experiments. The turtlegrass densities were within the range of natural densities in the northern Gulf of Mexico (Coen et al. 1981, Heck \& Thoman 1981).

Table 2. Densities of artifical seagrass, prey and predators $\left(\mathrm{m}^{-2}\right)$ in the different experimental treatments. In Expt 1 the compartment size in the bare sand treatment (first row) is double $\left(1.38 \mathrm{~m}^{2}\right)$ that of the other treatments $\left(0.68 \mathrm{~m}^{2}\right)$. In Expt 2 tank size was $1.48 \mathrm{~m}^{2}$ in all treatments

\begin{tabular}{|c|c|c|c|c|}
\hline & $\begin{array}{l}\text { Seagrass } \\
\text { density } \\
\left(\text { leaves } \mathrm{m}^{-2} \text { ) }\right.\end{array}$ & $\begin{array}{c}\text { Surface } \\
\text { area } \\
\left(\mathrm{m}^{2}\right)\end{array}$ & $\begin{array}{c}\text { Prey } \\
\text { density } \\
\text { (ind. } \mathrm{m}^{-2} \text { ) }\end{array}$ & $\begin{array}{c}\text { Predator } \\
\text { density } \\
\text { (ind. } \mathrm{m}^{-2} \text { ) }\end{array}$ \\
\hline \multicolumn{5}{|l|}{ Expt 1} \\
\hline Sand & 0 & 1.38 & 15 & 1.5 \\
\hline Low & 400 & 1.51 & 30 & 3 \\
\hline Intermediate & te 2000 & 4.80 & 100 & 10 \\
\hline High & 4000 & 8.92 & 190 & 19 \\
\hline \multicolumn{5}{|l|}{ Expt 2} \\
\hline Sand & 0 & 1.48 & 13.5 & 1.4 \\
\hline Low & 400 & 2.96 & 40.5 & 4 \\
\hline Intermediate & e 2000 & 8.88 & 203 & 20 \\
\hline High & 4000 & 16.28 & 405 & 40.5 \\
\hline
\end{tabular}

Table 1. Summary of basic experimental setup in Expts 1 and 2

\begin{tabular}{|lll|}
\hline & Expt 1 & Expt 2 \\
\hline Tank size (length $\times$ width $\times$ height); bottom area & $87 \times 78 \times 39 \mathrm{~cm}^{\circ} 0.68 / 1.38^{\mathrm{a}} \mathrm{m}^{2}$ & $124 \times 124 \times 73 \mathrm{~cm}^{2} 1.53 \mathrm{~m}^{2}$ \\
Sediment type & $5 \mathrm{~cm}$ sieved sand $(\varnothing=0.6 \mathrm{~mm})$ & $5 \mathrm{~cm}$ sieved sand $(\varnothing=0.6 \mathrm{~mm})$ \\
Artificial seagrass, width $\times$ height & Polypropylene ribbon, & $\begin{array}{l}\text { Polypropylene ribbon, } \\
\end{array}$ \\
Water depth & $0.5 \times 30 \mathrm{~cm}$ & $0.5 \times 25 \mathrm{~cm}$ \\
Salinity & $35 \mathrm{~cm}$ & $42 \mathrm{~cm}$ \\
Temperature & $18.5-20.1 \mathrm{psu}$ & $24.5-29.0 \mathrm{psu}$ \\
Pinfish Lagodon rhomboides size, mean $\pm \mathrm{SD}(\mathrm{n})$ & $26.3-30.1^{\circ} \mathrm{C}$ & $22.5-27.0^{\circ} \mathrm{C}$ \\
Grass shrimp Palaemonetes pugio size, mean $\pm \mathrm{SD}(\mathrm{n})$ & $88 \pm 9 \mathrm{~mm}(60)$ & $80 \pm 8 \mathrm{~mm}(401)$ \\
Experimental duration & $4.5 \pm 1.0 \mathrm{~mm}(99)$ & $5.0 \pm 1.3 \mathrm{~mm}(100)$ \\
Number of trials & $2 \mathrm{~h}$ & $4 \mathrm{~h}$ \\
Statistical analysis & 9 & 10 \\
a & 1 -way ANOVA & 1 -way ANOVA \\
\hline
\end{tabular}


In the experiments we used pinfish as the predator and grass shrimp as the prey (Table 1). The pinfish is the most common semidemersal fish species in seagrass habitats in the northern Gulf of Mexico (Stoner 1979, Darcy 1985), and grass shrimp are typical prey items that commonly co-occur in seagrass (Gore et al. 1981). Pinfish densities in low density SAV treatments (3 ind. $\mathrm{m}^{-2}$ ) were based on previously recorded densities in collections from turtlegrass habitats in the northern Gulf of Mexico (Heck et al. 2000, Spitzer et al. 2000). Shrimp densities (30 ind $\mathrm{m}^{-2}$ ) were also based on earlier field studies in seagrass habitats (Gore et al. 1981, Holmquist et al. 1989), and similar densities of grass shrimp have also been used in prior laboratory experiments (Coen et al. 1981).

The ratio between predators and prey abundance per unit of available surface area was kept constant at 1:10 in all treatments (Table 2). A constant ratio between the numbers of prey and predators over a gradient of vegetation densities is certainly an oversimplification of reality. However, since sufficient data on predator:prey ratios at different vegetation densities are lacking, we chose a constant ratio to facilitate the analysis of results. In recent studies, vegetation biomass and/or coverage and fish fauna (number of species, biomass and/or abundance) are positively correlated (Pierce et al. 1994, Wyda et al. 2002), which supports the relevance of our experimental design.

Available surface area was defined as the bottom area in each water table compartment combined with the total leaf surface area of the artificial grass (cf. Brown \& Lodge, 1993, Table 1). Leaf surface area is perhaps one of the best estimates of habitat complexity in seagrasses (Stoner 1979), and it was thus selected for use in our experiments. All $2 \mathrm{~h}$ experimental runs were conducted between 12:00 and 18:00 h. Prey were placed in the compartments $30 \mathrm{~min}$ before the fish were introduced to allow the shrimps time to seek cover and adjust to the experimental conditions before the pinfish were added. The 4 different treatments were repeated 9 times in a random order regarding both time and space, i.e. water table compartment (Table 1).

In the original bare sand treatment with 1 fish and 10 prey, predation efficiency of pinfish varied between 0 and $100 \%$ (survival of prey: $74.4 \pm 37.8 \%$, mean $\pm \mathrm{SD}, \mathrm{n}=9$ ). This variation was significantly higher than in the vegetation treatments (see 'Results' and 'Discussion'), and it was considered unacceptable. A likely reason for the uneven performance of the fish is that pinfish often hunt in groups (Luczkovich 1987, Jordan et al. 1996) and in this experiment only 1 fish was used. According to our pilot studies, the performance and predation efficiency of pinfish improved in the sand habitat when the number of fish (and prey) per compartment was increased. To be able to increase the number of fish in the sand treatment while maintaining the realism of the experimental treatments and still keeping the number of predators in proper proportion to the surface area available, trials were repeated in $1.38 \mathrm{~m}^{2}$ compartments with 2 fish per compartment. Accordingly, the number of prey was also doubled (Table 2) to keep a constant ratio (1:10) between predator and prey numbers. The same experimental procedures as for the other treatments were applied to the double-sized compartment. Thus, we believe that the trials in the double-sized compartments were comparable with the original trials.

The experimental compartments were illuminated with 2 fluorescent lights (40 W, 1.22 m Phillips AgroLite $^{\mathrm{TM}}$ ) placed $1 \mathrm{~m}$ above each compartment. The light intensity was comparable to mid-day light in the northern Gulf of Mexico (cf. James \& Heck 1994). After introducing the fish, the compartments were individually covered with a clear plastic film laid on the water surface to prevent shrimp from sticking to the compartment walls above the water surface while trying to escape predators. Similar barriers have been used in other experimental studies (Bartholomew et al. 2000). It is possible that the plastic film may have disturbed the natural escape behavior of the shrimp and thus led to higher predation rates than are present in nature. However, open tanks may also lead to complications, as shrimp are able to jump out of the tanks or stick to the tank walls and thus become unavailable to predators. We believe our choice to cover the compartments was the best way to deal with potential artifacts. Sufficient oxygen concentrations in the water were ensured by allowing a continuous slow water flow (ca. $50 \mathrm{ml} \mathrm{min}^{-1}$ ) during the experiments.

At the end of each trial most of the overlying water was drained through a sieve, and the grass mats were removed and washed over the sieve. All shrimp found in the grass were collected. The fish, as well as the remaining shrimp, were then collected from the compartments with a dip net. All surviving shrimp were counted.

Expt 2. To further test the hypothesis, another experiment was designed on the basis of the results from Expt 1. The main difference in this experimental setup was that we kept a constant ratio between total surface area of SAV only (and not area of SAV plus tank area) and numbers of predators and prey (Table 2). Expt 2 was conducted in September through November 2006 in 2 square tanks (bottom area $1.48 \mathrm{~m}^{2}$ when a corner filter area $[23 \times 25 \mathrm{~cm}]$ is subtracted from the total area, Table 1). A biofiltration system (Instant Ocean) operated continuously during the experiment. Habitat complexity and predator-prey ratios were identical to those in Expt 1 (Table 2). The experimental duration was $4 \mathrm{~h}$, and all experimental runs were conducted 
between 09:00 and 18:00 h. Both tanks were used in each run of the experiment, and the 4 different treatments were repeated 10 times in a random order for both time and space during a total of 20 runs (Table 1).

Water temperature and salinity followed natural patterns of variation and thus salinity values were somewhat higher than they were in Expt 1. In all other aspects the conditions and statistical analysis of the experiment were the same as in Expt 1 (Table 1).

\section{RESULTS AND DISCUSSION}

Mean survival of grass shrimp $(56.3 \pm 18.3 \%$, mean $\pm \mathrm{SD}$ ) in Expt 1 varied significantly among treatments (1-way ANOVA on arcsine transformed data, $F_{3,32}=$ 4.0926, p < 0.014) and was lowest in the sand treatment (Fig. 1a), where survival was significantly lower (Student-Newman-Keuls [SNK] test, p < 0.05) than in the intermediate and high density treatments, respectively, but not in the low density treatment. Other pairs of treatments did not differ significantly from each other. A post hoc power analysis estimated the power of the ANOVA to be $0.81\left(v_{1}=3, v_{2}=32, \phi=1.77\right)$ (Zar 1996), which can be considered acceptable when analyzing ecological data.

In Expt 2 mean survival of grass shrimp was (38.4 \pm $17.7 \%$, mean $\pm \mathrm{SD}$ ) and no significant differences were found among treatments (1-way ANOVA on arcsine transformed data, $F_{3,36}=1.867, \mathrm{p}=0.153$ ) (Fig. 1). The overall higher predation rate in Expt 2 was most likely due to a longer experimental duration ( $4 \mathrm{~h}$ in Expt 2 versus $2 \mathrm{~h}$ in Expt 1).

Another potentially important difference between experiments was that while in Expt 1 a linear increase of experimental animals in relation to available surface area (a constant ratio, e.g. ca. 1:1.4 between predator number and surface area) was maintained, this was not the case in Expt 2, where the numbers of experimental animals increased linearly only with SAV surface area and not total area in the tanks. The ratios of predator numbers to total available surface area $\left(\mathrm{m}^{2}\right)$ in Expt 2 for each condition were the following: sand, 1:1.3; 400 leaves $\mathrm{m}^{-2}, 1: 1.3 ; 2000$ leaves $\mathrm{m}^{-2}, 1: 3.4$; and 4000 leaves $\mathrm{m}^{-2}, 1: 3.7$. Although the predator numbers in Expt 2 increased in relation to surface area, which possibly could have increased consumption rates, there does not seem to be any clear pattern of this type of change across the treatments.

We evaluated the potential effects of different experimental duration and different numbers of predators in our experiments by comparing the data as prey consumption per individual predator and unit time. Calculations showed that the average individual consump-

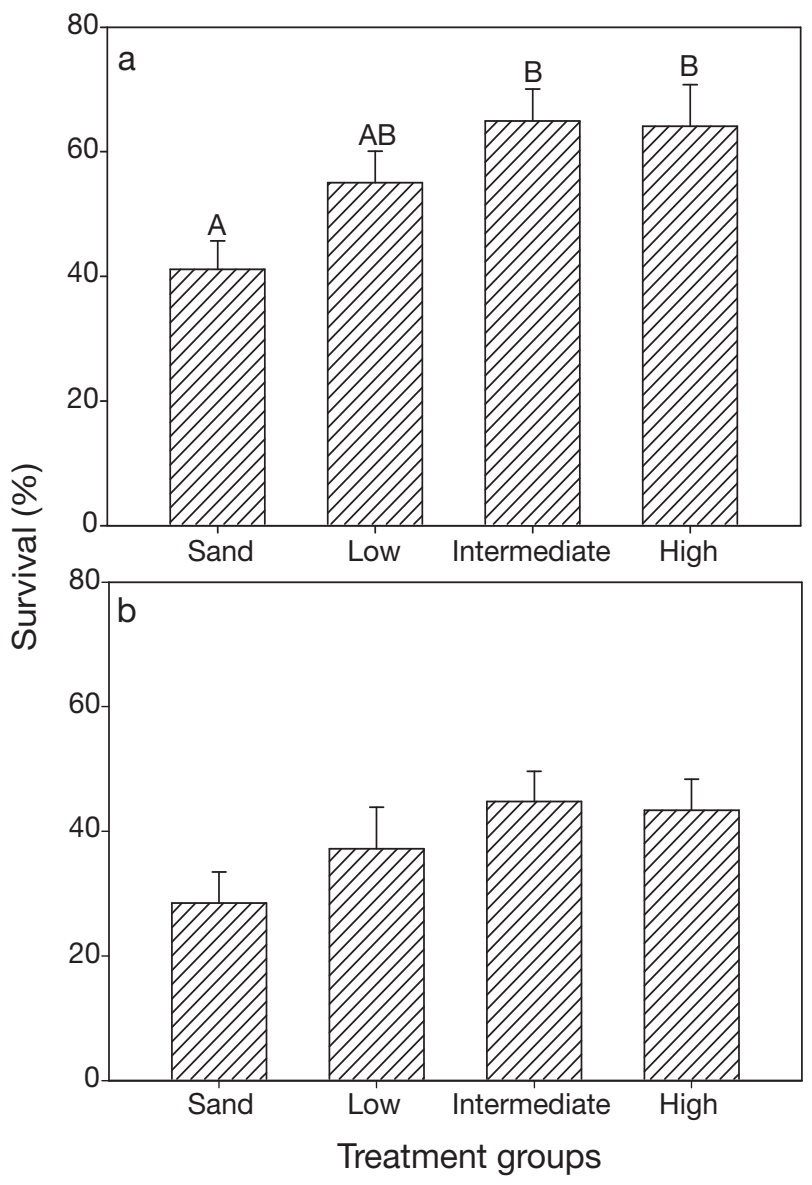

Fig. 1. Palaemonetes pugio. Percent survival of grass shrimp at different densities of artificial submerged aquatic vegetation in (a) Expt 1 and (b) Expt 2. Error bars indicate \pm 1 SE. Different capital letters above the bars denote homogeneous subsets according to Student-Newman-Keuls tests

tion rates varied between $5.1 \pm 2.0($ mean \pm SD) prey predator $^{-1} \mathrm{~h}^{-1}$ in the sand treatment in Expt 1 and $2.8 \pm$ 0.8 prey predator ${ }^{-1} \mathrm{~h}^{-1}$ in the high density treatment in Expt 2. Overall, the consumption rates were slightly higher in Expt 1, but only one significant difference in prey consumption existed between the experiments, and that was for the low density treatment ( $t$-test, $t=$ $2.844, \mathrm{df}=17, \mathrm{p}=0.011$ ). Due to this difference the data could not, however, be pooled across the experiments, so separate analyses were run for Expts 1 and 2. No significant differences in consumption rates were found for either of the experiments (Expt 1: 1-way ANOVA, $F_{3,32}=2.353, \mathrm{p}=0.091 ;$ Expt 2: 1-way ANOVA, $\left.F_{3,36}=1.867, \mathrm{p}=0.153\right)$. Thus, increasing complexity does not seem to considerably affect individual predator efficiency along a complexity gradient. Moreover, different experimental duration times did not consistently affect consumption rates, and no clear trend of decreasing consumption rates in high complexity treatments was found. 
We found no significant differences in grass shrimp survival among different densities of seagrass in either experiment. This conflicts with the conventional wisdom regarding the role of vegetation as shelter, but only, we believe, because the design of previous experiments unintentionally decreased the predator: prey ratio per unit of plant surface area as they experimentally increased seagrass density and surface area. In most experiments the predator:prey ratio has been held constant while the surface area has varied (e.g. Stoner 1979, Corona et al. 2000). This means that the numbers of predators and prey in dense vegetation treatments may have been lower than for comparable natural densities and thus predator-prey encounters have also been lower than that found in nature. Our data suggest that SAV provides more shelter than unvegetated substrate, but there is little difference among vegetation densities as long as the predator:prey ratio per unit surface area is kept constant. Our findings agree well with results from recent field experiments on juvenile cod Gadus spp. in artificial eelgrass Zostera marina L. In these experiments, Laurel et al. (2003) found that predation pressure was highest in unvegetated habitats. However, they found no difference in predation risk of single tethered prey items among artificial seagrass patches of varying size $\left(0.32\right.$ to $\left.22 \mathrm{~m}^{2}\right)$, i.e. in varying amounts of seagrass. This was explained by the increase in predator densities in the seagrass with increasing complexity, defined as a combination of seagrass density and patch size, which therefore kept the predation rates at a constant level in seagrass.

Based on our results, we also question the relevance of previous laboratory studies, including our own (e.g. Heck \& Thoman 1981, Mattila 1992), that effectively reduced the predator:prey ratio per unit plant surface area while investigating the effects of increasing SAV density on prey survival. These studies have probably led to incorrect generalizations regarding the manner in which SAV serves to shelter organisms. Instead, we suggest that when the predator:prey ratio per unit of plant surface area stays the same there is little difference in the amount of shelter available per individual prey with changing vegetation density. Therefore, from the perspective of an individual prey organism there is no significant benefit to inhabiting high density SAV (cf. Brown \& Lodge 1993), unless the predator:prey ratio is lower in the SAV than elsewhere. From the perspective of secondary production and fisheries concerns, however, it remains true that dense seagrass will produce greater yields than does sparse seagrass (e.g. Heck et al. 1989, Edgar \& Shaw 1995).

In conclusion, the findings of this study strongly suggest that broad generalizations made from most previous predator-prey studies in varying densities of sea- grass leaves may be inappropriate. Recent results from a field study show that, at least for territorial fish, high habitat complexity may increase predation risk (Rilov et al. 2007). However, it is clearly premature to generalize our results, and future experiments are needed to further clarify how different combinations of species of prey and predators as well as different kinds of vegetation influence outcomes. Also, the effects of varying predator:prey ratios in combination with the constant ratio model we present should be tested. However, our results show that it no longer seems safe to assume that increasing vegetation density will consistently lead to proportionally higher prey survival.

Acknowledgements. We thank Dr. George Crozier for providing excellent working facilities at the Dauphin Island Sea Lab, and Bryan King and Patricia Spitzer for help in collecting the experimental animals and conducting Expt 1. Drs. Erik Bonsdorff and John Valentine, and Ms. Patricia Spitzer kindly commented on earlier versions of this manuscript. This study was financially supported by the Academy of Finland, the Dauphin Island Sea Lab and the Alabama Center for Estuarine Studies (ACES). Dauphin Island Sea Lab Publication Number 390.

\section{LITERATURE CITED}

Bartholomew A, Diaz RJ, Cicchetti G (2000) New dimensionless indices of structural habitat complexity: predicted and actual effects on a predator's foraging success. Mar Ecol Prog Ser 206:45-58

> Boström C, Mattila J (1999) The relative importance of food and shelter for seagrass associated invertebrates - a latitudinal comparison of habitat choice by isopod grazers. Oecologia 120:162-170

Brown KM, Lodge DM (1993) Gastropod abundance in vegetated habitats: the importance of specifying null models. Limnol Oceanogr 38:217-225

Coen LD, Heck KL, Abele LG (1981) Experiments on competition and predation among shrimps of seagrass meadows. Ecology 62:1484-1493

Corona A, Soto LA, Sánchez AJ (2000) Epibenthic amphipod abundance and predation efficiency of the pink shrimp Farfantepeneus duorarum (Burkenroad, 1939) in habitats with different physical complexity in a tropical estuarine system. J Exp Mar Biol Ecol 253:33-48

Darcy GH (1985) Synopsis of biological data on the pinfish, Lagodon rhomboides (Pisces: Sparidae). NOAA Natl Mar Fish Serv Tech Rep 23, Seattle, WA

> Edgar GJ, Robertson AI (1992) The influence of seagrass structure on the distribution and abundance of mobile epifauna: pattern and process in a Western Australian Amphipolis bed. J Exp Mar Biol Ecol 160:13-31

Edgar GJ, Shaw G (1995) The production and trophic ecology of shallow-water fish assemblages in southern Australia. III. General relationships between sediments, seagrasses, invertebrates and fishes. J Exp Mar Biol Ecol 194:107-131

Gore RH, Gallagher EE, Scotto LE, Wilson KA (1981) Studies on decapod crustacea from the Indian River region of Florida. XI. Community composition, structure, biomass, and species-areal relationships of seagrass and drift algae-associated macrocrustaceans. Estuar Coast Shelf Sci 12:485-508

> Gotceitas V (1990a) Plant stem density as a cue in patch 
choice by foraging juvenile bluegill sunfish. Environ Biol Fishes 29:227-232

Gotceitas V (1990b) Variation in plant stem density and its effects on foraging success of juvenile bluegill sunfish. Environ Biol Fishes 27:63-70

Gotceitas V, Colgan P (1987) Selection between densities of artificial vegetation by young bluegills avoiding predation. Trans Am Fish Soc 116:40-49

Heck KL Jr, Thoman TA (1981) Experiments on predatorprey interactions in vegetated aquatic habitats. J Exp Mar Biol Ecol 53:125-134

Heck KL Jr, Able KW, Fahay MP, Roman CT (1989) Fishes and decapod crustaceans of Cape Cod eelgrass meadows: species composition, seasonal abundance patterns and comparison with unvegetated substrates. Estuaries 12:59-65

Heck KL Jr, Pennock JR, Valentine JF, Coen LR, Sklenar SA (2000) Effects of nutrient enrichment and small predator density on seagrass ecosystems: an experimental assessment. Limnol Oceanogr 45:1041-1057

> Holmquist JG, Powell GVN, Sogard SM (1989) Decapod and stomatopod assemblages on a system of seagrass-covered mud banks in Florida Bay. Mar Biol 100:473-483

> James PL, Heck KL (1994) The effects of habitat complexity and light intensity on ambush predation within simulated seagrass habitat. J Exp Mar Biol Ecol 176:187-200

Johns PM, Mann KH (1987) An experimental investigation of juvenile lobster habitat preference and mortality among habitats of varying structural complexity. J Exp Mar Biol Ecol 109:275-285

Jordan F, Bartolini M, Nelson C, Patterson PE, Soulen HL (1996) Risk of predation affects habitat selection by the pinfish, Lagodon rhomboides (Linnaeus). J Exp Mar Biol Ecol 208:45-56

Laprise R, Blaber SJM (1992) Predation by Moses perch, Lutjanus russelli, and blue-spotted trevally, Caranx bucculentus, on juvenile brown tiger prawn, Penaeus esculentus: effects of habitat structure and time of day. J Fish Biol 40:627-635

Laurel BJ, Gregory RS, Brown JA (2003) Predator distribution and habitat patch area determine predation rates on age-0 juvenile cod Gadus spp. Mar Ecol Prog Ser 251:245-254

Luczkovich JJ (1987) The patterns and mechanisms of selec-

Editorial responsibility: Otto Kinne,

Oldendorf/Luhe, Germany tive feeding on seagrass meadow epifauna by juvenile pinfish, Lagodon rhomboides (Linnaeus). PhD dissertation, Florida State University, Tallahassee

Mattila J (1992) The effect of habitat complexity on predation efficiency of perch (Perca fluviatilis L.) and ruffe (Gymnocephalus cernuus (L.)). J Exp Mar Biol Ecol 157:55-67

> Minello TJ, Zimmerman RJ (1983) Fish predation on juvenile brown shrimp, Penaeus aztecus Ives: the effect of simulated Spartina structure on predation rates. J Exp Mar Biol Ecol 72:211-231

> Orth RJ, Heck KL Jr, van Montfrans J (1984) Faunal communities in seagrass beds: a review of the influence of plant structure and prey characteristics on predator-prey relationships. Estuaries 7:339-350

Pierce CL, Rasmussen RB, Leggett WC (1994) Littoral fish communities in southern Quebec lakes: relationships with limnological and prey resource variables. Can J Fish Aquat Sci 51:1128-1138

- Rilov G, Figueira WF, Lyman SJ, Crowder LB (2007) Complex habitats may not always benefit prey: linking visual field with reef fish behavior and distribution. Mar Ecol Prog Ser 329:225-238

Savino JF, Stein RA (1982) Predator-prey interaction between largemouth bass and bluegills as influenced by simulated, submersed vegetation. Trans Am Fish Soc 111:255-266

Spitzer P, Mattila J, Heck KL Jr (2000) The effects of vegetation density on the relative growth rates, diet, and foraging behavior of pinfish, Lagodon rhomboides (L.), in Big Lagoon, Florida. J Exp Mar Biol Ecol 244:67-86

Stoner A (1979) Species-specific predation on amphipod crustacea by the pinfish Lagodon rhomboides: mediation by macrophyte standing crop. Mar Biol 55:201-207

Werner EE, Hall DJ, Laughlin DR, Wagner DJ, Wilsman LA, Funk FC (1977) Habitat partitioning in a freshwater fish community. J Fish Res Board Can 34:360-370

Wyda JC, Deegan LA, Hughes JE, Weaver MJ (2002) The response of fishes to submerged aquatic vegetation complexity in two ecoregions of the Mid-Atlantic Bight: Buzzards Bay and Chesapeake Bay. Estuaries 25:86-100

Zar JH (1996) Biostatistical analysis, 3rd edn. Prentice Hall, Upper Saddle River, NJ

Submitted: May 10, 2007; Accepted: January 7, 2008 Proofs received from author(s): May 29, 2008 